\title{
ANALISA KEBUTUHAN ENGLISH FOR SPECIFIC PURPOSE UNTUK PENDIDIKAN VOKASI
}

\author{
Tanzir Masykar \\ Prodi Konstruksi Pondasi, Beton, dan Pengaspalan Jalan \\ Jalan Iskandar Muda - Komplek STTU Alue Peunyareng, Meulaboh - Aceh Barat 23615 \\ Email : masykar.tanzir@gmail.com
}

\begin{abstract}
Abstrak - Mata kuliah Bahasa Inggris pada pendidikan vokasi merupakan mata kuliah umum (MKU) wajib. Berbeda dengan pendidikan di universitas, pendidikan vokasi menuntut konten pengajaran suatu mata kuliah dalam bentuk konten praktis. ESP, English for Sepcific Purpose adalah salah satu cabang ilmu pendidikan Bahasa Inggris yang dapat diterapkan dalam mengembangkan MKU Bahasa Inggris pada pendidikan vokasi. Studi pustaka ini menganalisis beberapa jurnal dan buku yang berkaitan dengan ESP dan mewawancarai dosen Bahasa Inggris pada tingkat universitas untuk menentukan materi Bahasa Inggris yang sesuai untuk pendidikan vokasi. Hasil kerangka need analysis (NA) Basturkmen dan Dudley-Evans, St John, \& Saint John, dipaparkan dan diuji dengan kebutuhan pendidikan vokasi jurusan mesin [1, 2]. Hasil kajian pustaka dan Analisa kebutuhan menunjukkan perlu adanya kurikulum, silabus, dan aktivitas berbeda untuk setiap jurusan pada pendidikan vokasi. Silabus Bahasa Inggris umum di perguruan tinggi tidak dapat dipakai sepenuhnya untuk kebutuhan pendidikan vokasi.
\end{abstract}

Kata kunci : Analisa Kebutuhan, English for Specific Purposes, Bahasa Inggris Umum, Pendidikan vokasi

Abstract - English courses in vocational education are compulsory general courses (MKU). In contrast to university education, vocational education demands the teaching content of a course in the form of practical content. ESP, English for Specific Purpose is one branch of English education that can be applied in developing the English course in vocational education. This literature study analyzes a number of journals and books related to ESP and English language lecturer studies at the university level to determine appropriate English material for vocational education. The results of the Basturkmen and Dudley-Evans, St John, \& Saint John's framework of need analysis are presented and tested with the vocational education needs of across three majors [1, 2]. The results of the literature review and need analysis indicate the need for different curriculum, syllabus, and activities for each department in vocational education. The general English syllabus in universities cannot be fully applied for vocational education needs.

Keywords: Needs analysis, English for Specific Purposes, General English, Vocational Education

\section{PENDAhuluan}

Kenyataan bahwa Bahasa bisa diajarkan sebagai alat komunikasi dibandingkan kemampuan grammar dan lexical membuat para ahli percaya bahwa Bahasa Inggris bisa diajarkan sesuai kebutuhan siswa [3]. Peserta didik yang belajar Bahasa Inggris di universitas tentunya berbeda dengan mereka yang belajar Bahasa Inggris pada sekolah penerbangan dan kelautan. Sekolah penerbangan dan kelautan memiliki kebutuhan Bahasa Inggris yang spesifik dan masuk dalam kategori pendidikan vokasi. Hal ini kemudian membuat lahirnya istilah ESP, English for Specificif Purposes sebagai bagian dari pendidikan Bahasa [2]. Di mana nantinya akan membutuhkan pendekatan sendiri untuk membuat kurikulum, menyusun materi, cara mendidik, menguji dan meneliti.

Pendidikan Vokasi berbeda dengan pendidikan tingkat tinggi di perguruan tinggi pada umumnya. Pendidikan vokasi masuk dalam ranah ilmu terapan bukan dalam tatanan teoritis [4, 5]. Lulusan dari perguruan tinggi vokasi diperuntukkan untuk langsung bisa bekerja, baik bekerja di perusahaan ataupun menciptakan lapangan kerja. Kebanyakan mata kuliah di vokasi adalah mata kuliah praktik yang dibarengi dengan tutorial di laboratorium.
Sebagaimana halnya perguruan tinggi, mata kuliah Bahasa Inggris termasuk mata kuliah umum yang wajib di setiap jurusan pada pendidikan vokasi. Mata kuliah Bahasa Inggris di perguruan tinggi tingkat sarjana biasanya terfokus pada kemampuan umum berbahasa Inggris seperti membaca, berbicara dan grammar. Mata kuliah Bahasa Inggris di Universitas Syiah Kuala misalnya lebih banyak menekankan grammar dan reading. Bahkan di Universitas Syiah Kuala ada beberapa pengajar yang menekankan pengajaran TOEFL untuk mata kuliah Bahasa Inggris. Hal ini dikarenakan setiap mahasiswa sarjana nantinya diwajibkan memenuhi nilai TOEFL tertentu pada akhir masa studinya.

Sebaliknya, mata kuliah Bahasa Inggris di pendidikan vokasi tidak boleh terfokus pada kemampuan umum dan teoritis. Kemampuan grammar dan reading tidak akan langsung bermanfaat kepada pelajar di pendidikan vokasi ketika nantinya mereka turun ke lapangan kerja. Sebaliknya, menitik beratkan mata kuliah Bahasa Inggris pada kemampuan grammar dan reading dapat menurunkan motivasi belajar siswa. Turunnya motivasi belajar siswa dapat berakibat pada gagalnya pencapaian pembelajaran $[6$, 7]. Di Akademi Komunitas Negeri Aceh Barat memiliki tiga program studi, DII Sipil, Mesin dan Elektro. Ketiga program 
studi ini adalah pendidikan vokasi dua tahun yang mana lulusannya diharapkan mampu bekerja mandiri atau bekerja pada sebuah perusahaan. Setiap program studi tentunya membutuhkan pembelajaran Bahasa Inggris yang berbeda sesuai dengan bidang masing-masing. Mahasiswa di program studi elektro mungkin akan berhadapan dengan buku manual pemasangan alat-alat listrik atau istilah-istilah Bahasa Inggris ketika mereka nantinya bekerja. Mahasiswa di program studi teknik mesin akan berhadapan dengan tutorial pengoperasian mesin yang bisa saja tertulis dalam Bahasa Inggris. Mahasiswa di prodi sipil mungkin perlu membaca skema atau perencanaan bangunan yang tertulis dalam Bahasa Inggris.

Jelas kebutuhan Bahasa Inggris pada setiap program studi ini sangat spesifik dan berbeda. Memaksa mahasiswa vokasi belajar Bahasa Inggris sebagaimana mata kuliah Bahasa Inggris di perguruan tinggi lainnya ada sebuah kekeliruan. Kurikulum Bahasa Inggris di perguruan tinggi lainnya dianggap sebagai mata kuliah umum sama dengan Pendidikan Agama, dan Pancasila. Oleh karena itu kurikulum tersebut tidak bisa digunakan sebagai acuan kurikulum mata kuliah Bahasa Inggris di pendidikan vokasi. Kurikulum baru perlu disusun untuk pendidikan vokasi dengan mempertimbangkan kebutuhan spesifik dari setiap studi[8]. Salah satu kajian pendidikan Bahasa inggris yang dapat digunakan sebagai acuan dalam membuat kurikulum pendidikan vokasi adalah ESP, English for Specific Purposes [9, 10]. Dalam menentukan materi yang diajarkan, Basturkmen [1] menyarankan untuk melakukan need analysis.

\section{Pertanyaan Penelitian}

1. Sejauh mana kurikulum Bahasa Inggris pada perguruan tinggi tingkat sarjana dapat digunakan sebagai acuan mata kuliah Bahasa Inggris di Pendidikan Vokasi.

2. Bagaimana bentuk kurikulum yang sesuai untuk pendidikan vokasi?

\section{METODE}

Artikel ini mengkaji berbagai buku dan artikel dari penelitian sebelumnya dalam bentuk kajian pustaka. Sebagai data pembanding, hasil wawancara empat dosen dari Universitas Syiah Kuala dan UIN Ar-Raniry yang diwawancarai menggunakan semistructured interview diperoleh untuk mengetahui silabus yang digunakan dalam mengajar mata kuliah umum di tingkat universitas. Hasil kajian pustaka dan wawancara kemudian dipaparkan secara deskriptif. Kerangka kurikulum pendidikan vokasi kemudian bangun dari hasil kajian pustaka dan wawancara.

\section{Tujuan Penelitian}

1. Untuk mengkaji kurikulum Bahasa Inggris pada perguruan tinggi tingkat sarjana dapat digunakan sebagai acuan mata kuliah Bahasa Inggris di Pendidikan Vokasi

2. Untuk menguji need analaysis sebagai dasar penyusunan kurikulum yang sesuai untuk pendidikan vokasi

\section{HASIL PENELITIAN}

\section{Definisi ESP}

ESP adalah sebuah kajian ilmu di bawah pendidikan Bahasa Inggris yang berfokus pada pengajaran Bahasa Inggris untuk tujuan khusus atau khalayak khusus. Cakupan ESP bisa sangat luas di mana TOEFL dan IELTS masuk dalam kategori ini. Day and Karzanowski [11] mendefinisikan huruf ' $\mathrm{P}$ ' pada ESP sebagai profesional. Di mana ESP nantinya mengajari skill tertentu yang sedang dibutuhkan siswa dalam pekerjaannya sekarang atau akan dibutuhkan ketika dia bekerja di masa akan datang. Namun definisi mereka tidak menganggap pengajaran Bahasa Inggri untuk ujian seperti Ujian PTE sebagai kajian ESP. Hanya Bahasa Inggris yang berhubungan dengan kerja dan bisnis dianggap sebagai ESP. Oleh karena itu ESP tidak mempertimbangkan ujian sebagai komponen penting. Meskipun tidak ada ujian dalam pengajaran Bahasa Inggris ESP, peserta didik diharapkan mampu mempelajari skill yang membentuk mereka di saat bekerja [11]. Pendidikan DII vokasi yang bertujuan mempersiapkan lulusan siap kerja sangat sejalan dengan definisi ESP secara umum. Kurikulum Bahasa Inggris di pendidikan vokasi dapat dikembangkan menggunakan kerangka pengajaran ESP.

\section{ESP VS General English}

ESP juga sangat berbeda dengan General English yang diajarkan sebagai mata kuliah umum di tingkat universitas untuk siswa dengan latar belakang pendidikan yang berbeda-beda. Oleh karena itu jika merujuk pada definisi ESP, General English yang diajarkan pada universitas tidak termasuk dalam kerangka ESP dan tentunya jelas tidak bisa digunakan pada pendidikan vokasi. Holme [12] mengatakan bahwa sifat silabus pendidikan Bahasa itu adalah selektif dan merupakan hasil dari analisa kebutuhan. Bahkan silabus General English saja perlu mempertimbangkan kebutuhan siswa dengan memproyeksikan kebutuhan nyata mereka akan Bahasa Inggris. Aktivitas yang dipilih oleh guru untuk diajarkan dalam kelas nantinya berasal dari hasil pertimbangan ini. Usaha sadar atau tidak sadar seorang guru memilah dan memilih aktivitas yang sesuai untuk siswanya adalah salah satu langkah awal dalam setiap pembuatan silabus pendidikan [12]. ESP sendiri adalah bentuk spesifik dari proses ini. Tomlinson [13] yakin bahwa perbedaan antara ESP dan General English tidaklah jelas. Dia mencontohkan, seorang pebisnis dari Korea perlu belajar Bahasa Inggris karena dia akan ditempatkan di luar negeri oleh perusahaannya. Namun, kemampuan bahasanya masih sangat minim dan kebanyakan materi yang diajarkan masih berkutat pada kemampuan dasar Bahasa Inggris. Apakah silabus Bahasa untuk siswa ini masuk dalam ESP atau

\section{General English?}

Oleh karena itu dalam membangun silabus, Holme [12] tidak menyarankan seorang guru memisahkan satu unit Bahasa dari rangkaiannya dan hanya mengajarkan bagian tersebut kepada calon siswa. Pendekatan yang holistik tetap dibutuhkan dalam membangun silabus Bahasa Inggris pada pendidikan vokasi. Fokus utama silabus Bahasa pada pendidikan vokasi harus menitik beratkan pada analisa kebutuhan, analisa teks, dan mempersiapkan siswa untuk bisa berkomunikasi dengan baik dalam kondisi kerjanya [2]. 
Need Analysis Bahasa Inggris untuk Pendidikan Vokasi

Need analysis (NA) adalah proses menentukan kebutuhan bahasa dan ketrampilan spesifik yang akan dibutuhkan oleh target pelajar. Dalam ESP NA mengacu pada proses pengembangan kursus. Dalam proses ini bahasa dan keterampilan yang akan digunakan peserta didik dalam target profesional atau tempat kerja kejuruan atau bidang studi mereka diidentifikasi dan dipertimbangkan dalam kaitannya dengan keadaan pengetahuan peserta didik saat ini, persepsi mereka tentang kebutuhan mereka dan kemungkinan praktis dan kendala konteks pengajaran.

Pada masa-masa awal munculnya ide NA, West [14] mengatakan kebanyakan guru berfokus pada kebutuhan dan objektif yang mewakili tujuan akhir dari perjalanan belajar seorang siswa. Namun seiring berjalannya waktu, NA menjadi semakin rumit $[15,16]$. Chambers [17] menyarankan agar NA harus berkaitan dengan pembentukan kebutuhan komunikatif dan realisasi akan kebutuhan tersebut, yang dihasilkan dari analisis komunikasi dalam situasi target yang di analisa.

Tujuan dari pembelajaran Bahasa Inggris di pendidikan vokasi untuk mengajarkan bahasa dan keterampilan komunikasi sesuai kebutuhan pelajar agar mereka bisa berkomunikasi secara efektif di tempat kerjanya. Oleh karena itu, seorang guru perlu melakukan NA terhadap kelas yang hendak diajarkan sebelum memutuskan kurikulum, silabus dan materi yang hendak dimasukkan dalam pengajaran Bahasa Inggris. Dudley-Evans, et al. [2] menawarkan 8 kriteria dalam melakukan need analysis:

1. Target situation analysis and objective needs: Informasi profesional tentang peserta didik: Tugas dan kegiatan yang sedang atau akan dihadapi pelajar dalam menggunakan bahasa Inggris.

2. Wants, means and subjective needs: Informasi pribadi tentang peserta didik: Faktor-faktor yang dapat mempengaruhi cara mereka belajar seperti pengalaman belajar sebelumnya, informasi budaya, alasan belajar dan harapan dari pembelajaran itu sendiri, dan sikap terhadap Bahasa Inggris.

3. Present situation analysis: Informasi bahasa Inggris tentang peserta didik: Bagaimana keadaan mereka saat ini, keterampilan dan penggunaan Bahasa Inggris mereka.

4. Lacks: Kekurangan peserta didik: Kesenjangan antara poin 3 dan poin 1 .

5. Learning needs: Informasi pembelajaran bahasa: Cara efektif untuk mempelajari keterampilan dan bahasa yang ditemukan pada poin 4 .

6. Linguistic analysis, discourse analysis, genre analysis: Informasi komunikasi profesional tentang poin 1: Pengetahuan tentang bagaimana bahasa dan keterampilan digunakan dalam situasi target

7. Course need: Apa yang diharapkan dari kursu

8. Mean analysis: Informasi tentang bagaimana kursus akan dijalankan

\section{Applikasi NA pada Mata Kuliah Bahasa Inggris di Pendidikan Vokasi}

Analisis kebutuhan sama seperti praktik kelas lainnya yang melibatkan keputusan berdasarkan minat, nilai, dan kepercayaan pengajaran, pembelajaran dan bahasa guru bersangkutan [18]. Kaewpet [19] menyebutkan bahwa ada dua tahap dalam perkembangan belajar siswa yang perlu dipertimbangkan dalam NA. Dia menghubungkan ESP dengan Zone of Proxima Development yang diperkenalkan oleh Vygotsky [20]. Proses NA ini kemudian dikerucutkan Basturkmen [1] yang melibatkan 5 proses:

1. Target situation analysis: Identifikasi tugas, kegiatan dan keterampilan peserta didik yang akan menggunakan bahasa Inggris untuk; apa yang seharusnya diketahui dan mampu dilakukan oleh peserta didik.

2. Discourse analysis: Deskripsi bahasa yang digunakan dalam konteks di atas.

3. Present situation analysis: Identifikasi apa yang diketahui atau tidak diketahui dan dapat atau tidak dapat dilakukan peserta didik sehubungan dengan tuntutan target situasi.

4. Learner factor analysis: Identifikasi faktor pembelajar seperti motivasi mereka, bagaimana mereka belajar dan persepsi mereka tentang kebutuhan mereka.

5. Teaching context analysis: Identifikasi faktorfaktor yang berkaitan dengan lingkungan tempat kursus berlangsung. Pertimbangan realistis mengenai apa yang dapat ditawarkan oleh Kursus dan guru ESP.

Tabel 1. Aplikasi konsep NA pada mata kuliah Bahasa Inggris Jurusan Teknik Mesin

\begin{tabular}{lll}
\hline No & $\begin{array}{l}\text { Need Analysis } \\
\text { Process }\end{array}$ & $\begin{array}{l}\text { Applikasi Konsep NA pada } \\
\text { Pendidikan Vokasi }\end{array}$ \\
\hline 1 & $\begin{array}{l}\text { Target situation } \\
\text { analysis }\end{array}$ & $\begin{array}{l}\text { Mampu mengoperasikan mesin } \\
\text { yang memiliki instruksi atau } \\
\text { tombol berbahasa Inggris }\end{array}$ \\
\hline 2 & $\begin{array}{l}\text { Discourse } \\
\text { analysis }\end{array}$ & $\begin{array}{l}\text { Bahasa perintah, frasa atau } \\
\text { kalimat-kalimat Bahasa Inggris } \\
\text { yang pendek }\end{array}$ \\
\hline 3 & $\begin{array}{l}\text { Present } \\
\text { situation } \\
\text { analysis }\end{array}$ & $\begin{array}{l}\text { Target siswa adalah lulusan } \\
\text { Sekolah Menengah yang } \\
\text { Bahasa Inggrisnya masih } \\
\text { dalam kategori dasar }\end{array}$ \\
\hline 4 & Learner factor \\
analysis & $\begin{array}{l}\text { Berdasarkan laporan dari } \\
\text { beberapa guru sebagian besar } \\
\text { siswa kurang termotivasi untuk } \\
\text { belajar Bahasa Inggris. }\end{array}$ \\
\hline 5 & $\begin{array}{l}\text { Teaching } \\
\text { context analysis }\end{array}$ & $\begin{array}{l}\text { Fasilitas umum seperti } \\
\text { whiteboard dan proyektor } \\
\text { tersedia di tempat belajar } \\
\text { namun alat peraga mesin yang } \\
\text { Berbahasa Inggris masih perlu } \\
\text { kajian lebih lanjut. }\end{array}$ \\
& &
\end{tabular}

Tabel 2. Applikasi konsep NA pada mata kuliah Bahasa Inggris jurusan teknil sipil dan pengaspalan jalan

\begin{tabular}{llll}
\hline No & $\begin{array}{l}\text { Need Analysis } \\
\text { Process }\end{array}$ & $\begin{array}{l}\text { Applikasi Konsep NA pada } \\
\text { Pendidikan Vokasi }\end{array}$ \\
\hline 1 & $\begin{array}{l}\text { Target situation } \\
\text { analysis }\end{array}$ & $\begin{array}{l}\text { Mampu memahami denah } \\
\text { perencanaan yang ditulis } \\
\text { dalam Bahasa Inggris }\end{array}$ \\
\hline 2 & $\begin{array}{l}\text { Discourse } \\
\text { analysis }\end{array}$ & $\begin{array}{l}\text { Bahasa perintah, frasa atau } \\
\text { kalimat-kalimat Basa }\end{array}$ \\
& & Inggris yang pendek & Bahasa \\
& & &
\end{tabular}




\begin{tabular}{|c|c|c|}
\hline \multirow[t]{4}{*}{3} & \multirow{4}{*}{$\begin{array}{l}\text { Present situation } \\
\text { analysis }\end{array}$} & Target siswa \\
\hline & & Sekolah Menengah yang \\
\hline & & Bahasa Inggrisnya \\
\hline & & dalam kategori dasar \\
\hline 4 & $\begin{array}{l}\text { Learner } \\
\text { analysis }\end{array}$ & $\begin{array}{l}\text { Berdasarkan laporan dar } \\
\text { beberapa guru sebagian besa } \\
\text { siswa kurang termotivas } \\
\text { untuk belajar Bahasa Inggris. }\end{array}$ \\
\hline 5 & $\begin{array}{l}\text { Teaching context } \\
\text { analysis }\end{array}$ & $\begin{array}{l}\text { Fasilitas umum sepert } \\
\text { whiteboard dan proyektor } \\
\text { tersedia di tempat belajar } \\
\text { namun alat peraga denah yang } \\
\text { Berbahasa Inggris masih perlu } \\
\text { kajian lebih lanjut. }\end{array}$ \\
\hline
\end{tabular}

Tabel 3. Applikasi konsep NA pada mata kuliah Bahasa Inggris jurusan teknik sipil dan pengaspalan jalan

\begin{tabular}{|c|c|c|}
\hline No & $\begin{array}{l}\text { Need Analysis } \\
\text { Process }\end{array}$ & $\begin{array}{l}\text { Applikasi Konsep NA pada } \\
\text { Pendidikan Vokasi }\end{array}$ \\
\hline 1 & $\begin{array}{l}\text { Target situation } \\
\text { analysis }\end{array}$ & $\begin{array}{l}\text { Mampu memahami instruksi } \\
\text { pemasangan peralatan listrik } \\
\text { dalam Bahasa Inggris }\end{array}$ \\
\hline 2 & $\begin{array}{l}\text { Discourse } \\
\text { analysis }\end{array}$ & $\begin{array}{l}\text { Bahasa perintah, frasa atau } \\
\text { kalimat-kalimat } \\
\text { Inggris yang pendek }\end{array}$ \\
\hline 3 & $\begin{array}{l}\text { Present situation } \\
\text { analysis }\end{array}$ & $\begin{array}{lr}\text { Target siswa adalah lulusan } \\
\text { Sekolah Menengah yang } \\
\text { Bahasa Inggrisnya masih } \\
\text { dalam kategori dasar }\end{array}$ \\
\hline 4 & $\begin{array}{l}\text { Learner } \\
\text { analysis }\end{array}$ & $\begin{array}{l}\text { Berdasarkan laporan dari } \\
\text { beberapa guru sebagian besar } \\
\text { siswa kurang termotivasi } \\
\text { untuk belajar Bahasa Inggris. }\end{array}$ \\
\hline 5 & $\begin{array}{l}\text { Teaching context } \\
\text { analysis }\end{array}$ & $\begin{array}{l}\text { Fasilitas umum } r \text { seperti } \\
\text { whiteboard dan proyektor } \\
\text { tersedia di tempat belajar } \\
\text { namun alat peraga berupa } \\
\text { peralatan listrik } \\
\text { memiliki instruksi Berbahasa } \\
\text { Inggris masih perlu kajian } \\
\text { lebih lanjut. }\end{array}$ \\
\hline
\end{tabular}

\section{KESIMPULAN}

Dari hasil kajian pustaka ini dapat kita disimpulkan bahwa kurikulum General English tidak dapat digunakan sepenuhnya untuk pendidikan vokasi. ESP dapat menjadi rujukan penyusunan kurikulum Bahasa Inggris di Pendidikan Vokasi. Need analaysis juga menunjukkan bahwa situasi target penggunaan Bahasa Inggris sangat berbeda dengan General English. Meskipun bentuk kalimat yang umum terpapar oleh siswa ketika bekerja nantinya dalam bentuk Bahasa instruksi dan perintah, aktivitas dan alat peraga yang diperlukan di setiap jurusan sangat berbeda.
Silabus umum untuk setiap jurusan bisa sama namun aktivitas dan alat peraga selama perkuliahan akan berbeda. Studi selanjutnya disarankan untuk fokus pada penyusunan, kurikulum, silabus aktivitas, alat peraga untuk setiap jurusan dan melakukan penelitian tindakan kelas terhadap materi yang disusun.

\section{REFERENSI}

[1] H. Basturkmen, Developing courses in English for specific purposes: Springer, 2010.

[2] T. Dudley-Evans, M. J. St John, and M. J. Saint John, Developments in English for specific purposes: A multidisciplinary approach: Cambridge university press, 1998.

[3] D. Nunan, Task-Based Language Teaching. Cambridge: Cambridge University Press, 2004.

[4] P. R. INDONESIA, "Undang-undang Republik Indonesia nomor 20 tahun 2003 tentang sistem pendidikan nasional," 2006.

[5] R. Indonesia, "Undang-undang Republik Indonesia nomor 20 tahun 2003 tentang sistem pendidikan nasional," Jakarta: Pemerintah Republik Indonesia, 2003.

[6] T. Urdan and E. Schoenfelder, "Classroom effects on student motivation: Goal structures, social relationships, and competence beliefs," Journal of school psychology, vol. 44, pp. 331-349, 2006.

[7] J. L. Meece, E. M. Anderman, and L. H. Anderman, "Classroom goal structure, student motivation, and academic achievement," Annu. Rev. Psychol., vol. 57, pp. 487-503, 2006.

[8] R. Arellano, T. Masykar, and A. Almulhim, "The Rationale for A Proposal for English Language Education: The Experience of Developing A Curriculum to Teach English for Young Learners," presented at the 1st Aceh Global Conference (AGC 2018), Aceh, 2019

[9] H. P. Widodo, "Teaching English for specific purposes (ESP): English for vocational purposes (EVP)," in English language teaching today, ed: Springer, 2016, pp. 277-291.

[10] T. Hyland, "On the upgrading of vocational studies: Analysing prejudice and subordination in English education," Educational Review, vol. 54, pp. 287-296, 2002

[11] J. Day and M. Karzanowski, Teaching English for Specific Purposes: An Introduction Cambridge: Cambridge University Press, 2011.

[12] R. Holme, "ESP ideas. Edinburgh: Gate," ed: Longman Group UK Limited, 1996.

[13] B. Tomlinson, Developing materials for language teaching: A\&C Black, 2003.

[14] R. West, "Needs analysis: State of the art," Teacher education for LSP, pp. 68-79, 1997.

[15] A. Tajino, R. James, and K. Kijima, "Beyond needs analysis: soft systems methodology for meaningful collaboration in EAP course design," Journal of English for Academic Purposes, vol. 4, pp. 27-42, 2005.

[16] R. West, "Needs analysis in language teaching," Language teaching, vol. 27, pp. 1-19, 1994.

[17] F. Chambers, "A re-evaluation of needs analysis in ESP," The ESP Journal, vol. 1, pp. 25-33, 1980.

[18] K. Hyland, Genre and second language writing: University of Michigan Press, 2004.

[19] C. Kaewpet, "A framework for investigating learner needs: Needs analysis extended to curriculum development," Electronic journal of foreign language teaching, vol. 6, pp. 209-220, 2009.

[20] L. S. Vygotsky, Mind in society: The development of higher psychological processes: Harvard university press, 1980. 